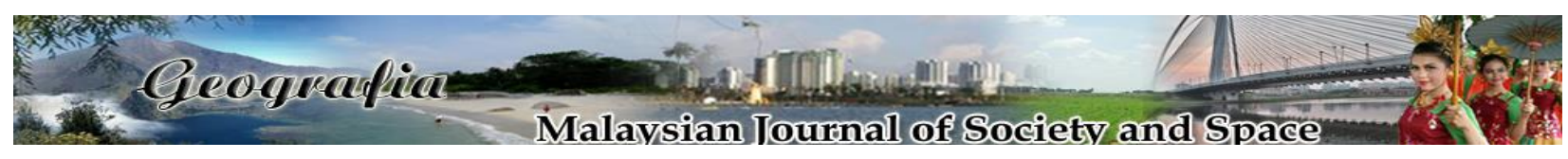

\title{
Tahap kesedaran komuniti pinggir pantai terhadap kenaikan aras laut
}

\author{
Noorazuan Md Hashim, Zaini Sakawi, Lam Kouk Choy, Mokhtar Jaafar, Rosniza Aznie Che Rose, \\ Nor Hasyifa Ahmad
}

Program Geografi, Pusat Pembangunan, Sosial dan Persekitaran, Fakulti Sains Sosial dan Kemanusiaan, Universiti Kebangsaan Malaysia

Correspondence: Noorazuan Md Hashim (email: azwan@ukm.edu.my)

Received: 23 January 2019; Accepted: 14 April 2019; Published: 14 May 2019

\begin{abstract}
Abstrak
Komuniti pinggir pantai merupakan golongan yang paling terdedah kepada bahaya perubahan kenaikan paras laut di Malaysia. Walaupun negeri Selangor tidak termasuk di dalam zon kritikal kenaikan aras laut, namun faktor lokasi petempatan yang berhampiran garis pantai serta topografi yang rendah berupaya mencetuskan bencana pada masa hadapan. Justeru itu, makalah ini bertujuan mengenal pasti tahap pengetahuan dan kesedaran komuniti pinggir pantai terhadap perubahan iklim dan kenaikan aras laut. Sebanyak 1050 responden telah dipilih secara rawak bagi tujuan tinjauan soal selidik di sekitar sepuluh petempatan utama zon pesisir pantai di Selangor, bermula dari Bagan Nakhoda Omar, Sabak Bernam sehinggalah ke Tanjung Sepat, Kuala Langat, Selangor. Di samping itu, temu bual informan utama dan diskusi kumpulan fokus, khususnya komuniti nelayan pinggir pantai telah dilakukan. Hampir 70 peratus daripada responden sedar terhadap isu berkaitan perubahan iklim dan pengaruhnya terhadap kesihatan manusia menjadi kenyataan yang paling kerap dikaitkan. Bagaimanapun, kesedaran tentang bahaya perubahan iklim kepada peningkatan aras laut mengambarkan peratusan yang sederhana. Hasil kajian membuktikan responden berbangsa Melayu mempunyai nilai skor tertinggi untuk konstruk pengetahuan, kesedaran dan tanggapan terhadap perubahan iklim. Hasilan tahap keprihatinan perubahan iklim menunjukkan kawasan Sg. Nibong, Kuala Selangor mempunyai tahap keprihatinan tertinggi (nilai indeks $=0.971$ ), manakala Kg. Batu Laut, Kuala Langat mempunyai nilai keprihatinan paling rendah (nilai indeks $=0.183$ ). Kajian ini telah membuktikan wujudnya perbezaan kesedaran dan keprihatinan komuniti pinggir pantai terhadap perubahan iklim dan kenaikan aras laut berdasarkan lokasi petempatan dan kumpulan bangsa. Adalah diharapkan, hasil kajian ini berupaya memberi maklumat penting kepada pihak penguasa dalam pengurusan dan perancangan program adaptasi serta penyesuaian terhadap sebarang bencana berkaitan kenaikan paras laut.
\end{abstract}

Katakunci: kenaikan aras laut, keprihatinan, komuniti, perubahan iklim, pinggir pantai, variabiliti 


\title{
Coastal community's awareness and concern on sea level rise
}

\begin{abstract}
The coastal community is the group most affected by sea level rise hazard in Malaysia. Although the state of Selangor is excluded from the critical zone of sea level rise, however the proximity of coastal dwellings to shoreline and low coastal topography may trigger catastrophe in the future. This paper aims to identify the level of knowledge and awareness of the coastal community towards climate change and sea level rise. A total of 1050 respondents were randomly selected through survey ranging from Bagan Nakhoda Omar, Sabak Bernam to Tanjung Sepat, Kuala Langat, Selangor. In addition, main informant interviews and focus group discussions, especially coastal fishing communities, were also conducted. Nearly 70 per cent of respondents are aware of issues related to climate change and their impact on human health has become the most influential to coastal dwellers. However, the reponsdents' awareness on the dangers of climate change to the sea level rise shows an average result at 43 percent. The findings show that Malay respondents have the highest score for knowledge constructs, awareness and perceptions of climate change. The climate change awareness level shows Sg. Nibong, Kuala Selangor has the highest level (index value $=0.971$ ), while $\mathrm{Kg}$. Batu Laut, Kuala Langat has the lowest value (index value $=0.183$ ). The study showed differences between the awareness and concern of coastal community towards climate change and sea level rise based on location of settlements and between groups of people. It is hoped that this study will be able to provide significant information to relevent authorities in management and planning of adaptation programs as well as adaptation to any disaster associated to sea level rise.
\end{abstract}

Keywords: sea level rise, awareness, community, climate change, coastal line, variability

\section{Pengenalan}

Malaysia merupakan sebuah negara maritim yang mempunyai ekosistem garis pantai semulajadi sepanjang 4,800 km. Kedudukannya di atas Pentas Sunda yang cetek dan stabil dari segi geologi telah menggalakkan aktiviti petempatan dan perikanan di zon pinggir pantai. Komuniti pinggir pantai dianggap golongan yang paling terdedah kepada sebarang bencana akibat perubahan kenaikan paras laut di Malaysia. Walaupun negeri Selangor tidak dianggap zon yang sangat terkesan dengan kenaikan paras laut (melebihi $0.4 \mathrm{~m}$ pada tahun 2100) berdasarkan kajian oleh pihak NAHRIM (2010), namun faktor lokasi petempatan yang berhampiran garis pantai serta topografi yang rendah mampu mencetuskan bencana pada masa hadapan.

Penelitian terhadap perubahan aras laut dan impaknya kepada komuniti pinggir pantai di Malaysia dianggap suatu gerak kerja yang penting memandangkan zon pinggir pantai didominasi dengan populasi penduduk yang ramai serta pusat sosioekonomi yang berasaskan kepada aktiviti maritim. Kajian pemodelan oleh IPI (2015) di sekitaran Batu Pahat, Johor mendapati kenaikan paras laut berupaya memberi impak negatif kepada kawasan zon pesisir pantai seperti kemusnahan jaringan infrastruktur jalan raya, bangunan kediaman serta ekosistem semula jadi seperti litupan vegetasi bakau. 
Dianggarkan menjelang tahun 2100, jumlah penduduk Malaysia yang terjejas akibat kenaikan aras laut adalah kira-kira 1.5 juta orang, termasuklah di Sabah dan Sarawak (Ahmad Jamaluddin, 2008). Impak terhadap kenaikan aras laut tidak boleh dibahaskan dalam konteks jumlah populasi yang terjejas semata-mata. Ini adalah kerana, bahaya, ancaman dan risiko kenaikan aras laut bukan sahaja terhadap populasi, malahan ianya juga melibatkan perubahan ekistiks iaitu yang berkaitan dengan pola petempatan serta aspek sosiobudaya manusia setempat.

Maklumat berkaitan persepsi masyarakat juga boleh menentukan arah tuju pembangunan, kegunaan tenaga, komersil dan industri di masa hadapan. Kadangkala, wujud perbezaan pandangan dan persepsi di antara pihak awam dan pihak profesional (Slovic, 2001; Priskin, 2003). Justeru itu, kajian ini bertujuan mengenal pasti tahap pengetahuan dan kesedaran komuniti pinggir pantai terhadap bencana akibat perubahan iklim dan kenaikan aras laut. Kajian persepsi masyarakat pinggir pantai di Selangor ini diharap membuka lembaran baharu mengenai hala tuju program pembangunan dan adaptasi serta menjangkakan kuantifikasi tahap keupayaan menanggung bencana oleh individu dan masyarakat.

\section{Kajian literatur}

Teori perubahan iklim dipelopori oleh saintis British, John Tyndall pada tahun 1859 telah mengemukakan teori kuasa penyerapan dan penyerakan haba oleh gas karbon dioksida berbanding dengan pelbagai jenis gas lain yang wujud di atmosfera (Noorazuan, 2015). Idea penyerapan radiasi haba oleh gas karbon dioksida telah dikaitkan secara tidak rasmi dengan fenomena pemanasan sedunia (global warming). Bukti arkeologi terdahulu juga menunjukkan bahawa sesetengah petempatan awal manusia mungkin dipengaruhi oleh perubahan persekitaran (Jamaluddin, 2011). Di Semenanjung Malaysia, perubahan aras laut sejak 10,000 tahun yang lepas akibat kenaikan suhu global dikatakan telah mempengaruhi beberapa petempatan manusia di delta sungai dan juga di pesisiran pantai (Tjia, 1987).

Perubahan iklim bukan sahaja meninggalkan pengaruh negatif terhadap kemampanan sumber air mentah di Selangor, malahan ia juga mampu mengubah keseimbangan dan turun-naik paras air laut. Kesan pemanasan global yang mengakibatkan pencairan glasier dengan kadar yang belum pernah terjadi sebelum ini merupakan faktor pencetus kepada fenomena kenaikan paras laut di seluruh dunia. Perubahan aras laut adalah salah satu bentuk bencana yang terhasil akibat daripada perubahan iklim global (IPCC, 2013; Hansen, 2013). Kenyataan ini tidak dapat disangsikan lagi dengan adanya kajian terkini yang menggunakan maklumat saintifik, termasuklah penggunaan satelit altimeter yang mampu mengesan sebarang perubahan di kawasan pesisiran pantai (Rajah 1). 


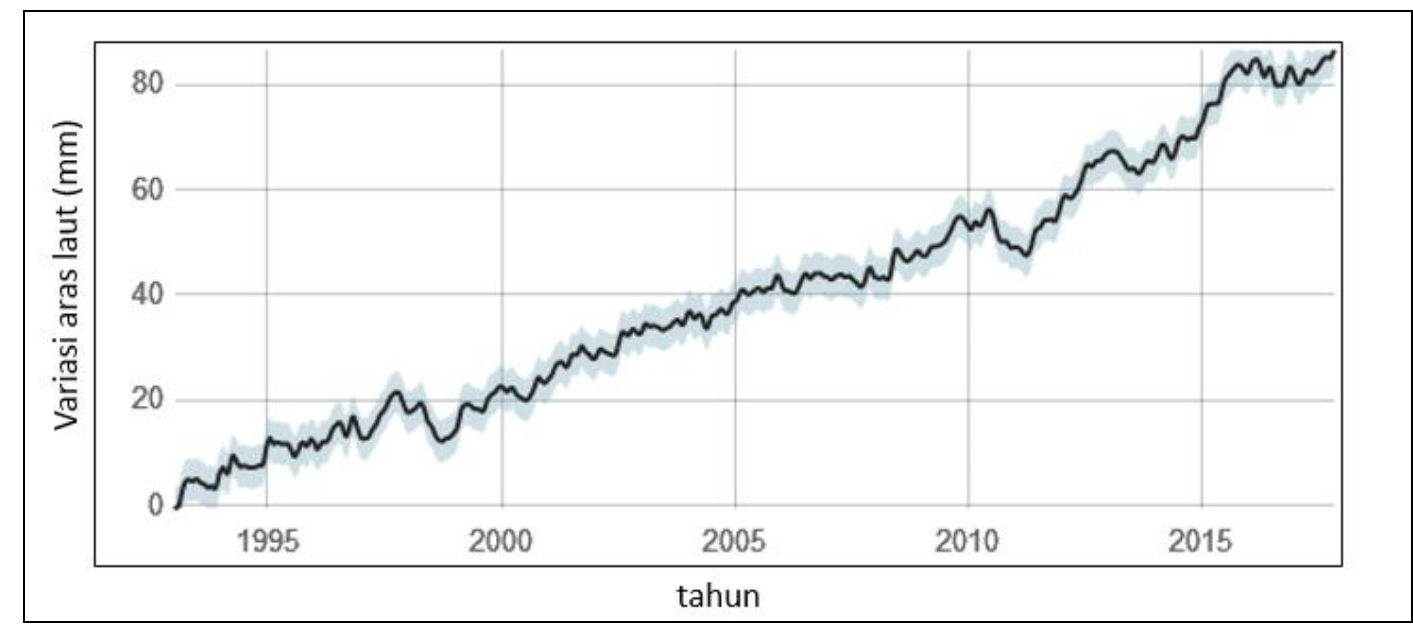

Sumber: NASA, 2018.

Rajah 1. Perubahan aras laut bermula dari tahun 1995 hingga kini

Menurut Nicholls et al. (2009) kenaikan aras laut yang disebabkan oleh pemanasan global juga telah mempengaruhi sistem kitaran hidupan marin dan ekosistem pesisiran pantai. Ekoran daripada itu, fenomena berkenaan secara tidak langsung mempengaruhi kehidupan manusia, terutamanya kepada mereka yang bergantung hidup kepada ekosistem marin dan pantai. Hakisan, penyusutan daratan dan penerobosan air masin juga telah meningkatkan lagi kemudahterancaman manusia di pesisiran laut (Bird, 1985).

Ramalan peningkatan aras laut di Malaysia iaitu sebanyak 2.7-7.0 mm/tahun adalah melebihi ramalan kenaikan aras laut global iaitu diantara 1.7-3.1 mm/tahun (Nor Aslinda \& Mohd Radzi, 2013). Perbezaan yang besar bakal dialami di Malaysia memandangkan faktor negara maritim, di samping keterdedahan perubahan iklim tempatan dan faktor topografi yang rendah di kawasan pinggir pantai. Manakala wilayah pinggir pantai yang paling teruk terjejas adalah di Utara Semenanjung, termasuk Kedah, Pulau Pinang dan Perak (Jadual 1). Namun, negeri persisir laut seperti Selangor tidak boleh memandang ringan terhadap sebarang perubahan dan bahaya daripada persekitaran marin. Justeru itu, makalah ini bertujuan mengenal pasti tahap pengetahuan dan kesedaran oleh komuniti pinggir pantai terhadap perubahan iklim dan kenaikan paras laut.

Jadual 1. Unjuran kenaikan paras laut tahunan di pinggir pantai Semenanjung Malaysia

\begin{tabular}{lc}
\hline Lokasi & $\begin{array}{c}\text { Kadar kenaikan aras laut } \\
\text { (mm/tahun) }\end{array}$ \\
\hline Perairan Selat Melaka & 3.68 \\
Perairan Laut Andaman & 3.87 \\
Selat Johor & 2.88 \\
Sempadan Malaysia (Perlis) & 6.08 \\
Sempadan P.Pinang-Perak & 6.45 \\
Perairan Mersing & 2.73 \\
Perairan Kelantan & 5.02 \\
Selat Johor & 2.88 \\
\hline
\end{tabular}

Sumber: Nor Aslinda \& Mohd Radzi, 2013. 
Menurut Bindoff et al. (2007), terdapat tiga faktor pencetus kepada kenaikan paras laut global; pertama, peningkatan suhu (dan tenaga) laut, kedua, pencairan glasier di Greenland dan Antartika dan ketiganya, perubahan storan sumber air daratan. Ramai penyelidik dalam dan di luar negara berpandangan isu perubahan iklim dan kenaikan paras laut merupakan suatu yang boleh dilihat dalam konteks 'sebab dan akibat' (Bindoff et al., 2007; IPCC, 2013; Hansen, 2013; Noorazuan, 2015). Justeru itu, perubahan iklim seperti perubahan suhu ambien, taburan hujan yang tidak normal dan kejadian ekstrem, ditambah dengan kenaikan paras laut menggambarkan peningkatan skala bahaya dan bencana di masa akan datang.

Kesan utama kenaikan aras laut adalah kawasan dataran pantai bertopografi rendah dan muara sungai berpotensi ditenggelami air dan mengalami banjir laut. Keluasan tanah akan semakin berkurangan dan berlakunya kehilangan tanah penduduk (IPI 2015). Impak berkenaan berupaya meningkatkan tahap kemudahterancaman individu dan komuniti, malahan status sosioekonomi terkini yang rendah bakal mengurangkan usaha untuk mengadaptasikan kehidupan individu dan komuniti di masa akan datang (Hobfoll et al., 2007; Shear et al., 2011). Penambahan populasi dan pembangunan pesat di zon pinggir laut pada masa akan datang bakal menambahkan lagi tahap risiko bencana kenaikan paras laut, khususnya negara maritim seperti Malaysia.

Secara ilmiahnya, aspek variabiliti dan perubahan iklim adalah dua fenomena yang berbeza. Cuaca boleh berubah dari masa ke semasa dan ianya bergantung kepada keadaan atmosfera kita. Namun, dari jangka masa panjang, wujud juga variabiliti iklim yang berubah akibat faktor semulajadi. Diantaranya adalah seperti kehadiran fenomena El-Nino/La Nina. Variabiliti iklim secara semula jadi adalah sangat berbeza dengan perubahan iklim yang biasanya dikaitkan dengan pengaruh antropogenik, pembakaran karbon dan gas rumah hijau.

Hasil laporan impak perubahan iklim terhadap aspek kesihatan (The Lancet, 2017) mendedahkan dunia kini berada di tahap yang amat membimbangkan dan ianya bakal mengancam kesihatan jutaan penduduk dunia ekoran peningkatan mendadak penyakit dan masalah kesihatan yang kronik. Hasil laporan berkenaan juga telah membuktikan secara kuantitatif tentang penurunan tahap produktiviti buruh dalam kalangan pekerja ladang disebabkan perubahan cuaca yang menjejaskan tenaga pekerja terutamanya di India dan Brazil. Negara Malaysia walaupun bukan dalam kalangan negara pengeluar karbon terbesar dunia, namun ia merupakan sebuah negara maritim yang berpotensi menghadapi impak peningkatan paras aras laut.

Rajah 2 menunjukkan hubungan teoritikal di antara keterdedahan bencana perubahan iklim dengan aspek sfera komuniti. Di dalam sfera komuniti atau masyarakat, tiga elemen penting yang membentuk aspek kemudahterancaman, iaitu sensitiviti, daya tahan dan adaptasi. Keterdedahan kepada bencana adalah sangat bergantung kepada frekuensi dan magnitud bencana, di mana dalam konteks ini adalah perubahan iklim yang ekstrim. Negara-negara yang terletak di wilayah Asia Pasifik sangat terdedah dengan bencana perubahan iklim seperti haba melampau semasa musim kering, berpotensi membawa kepada strok haba dan juga kanser kulit (The Lancet, 2017).

Blaikie et al. (1994) menyatakan kemudahterancaman komuniti atau masyarakat sangat berbeza dari satu lokasi ke lokasi yang lain. Ianya sangat bergantung kepada elemen-elemen yang dimaksudkan (Rajah 2), iaitu hubung kaitan sensitiviti-daya tahan-adaptasi. Pengukuran terhadap ketiga-tiga elemen berkenaan bukanlah sesuatu yang bersifat objektif, malahan ianya lebih bersifat subjektif dan kadangkala ianya diukur melalui gabungan atau penyatuan pelbagai item atau pembolehubah yang membentuk suatu indeks. Ada kalanya para penyelidik terpaksa 
membangunkan suatu bentuk kajian survei yang dapat menghasilkan data yang mencukupi untuk menilai tahap sensitiviti masyarakat terhadap sebarang bentuk bencana.

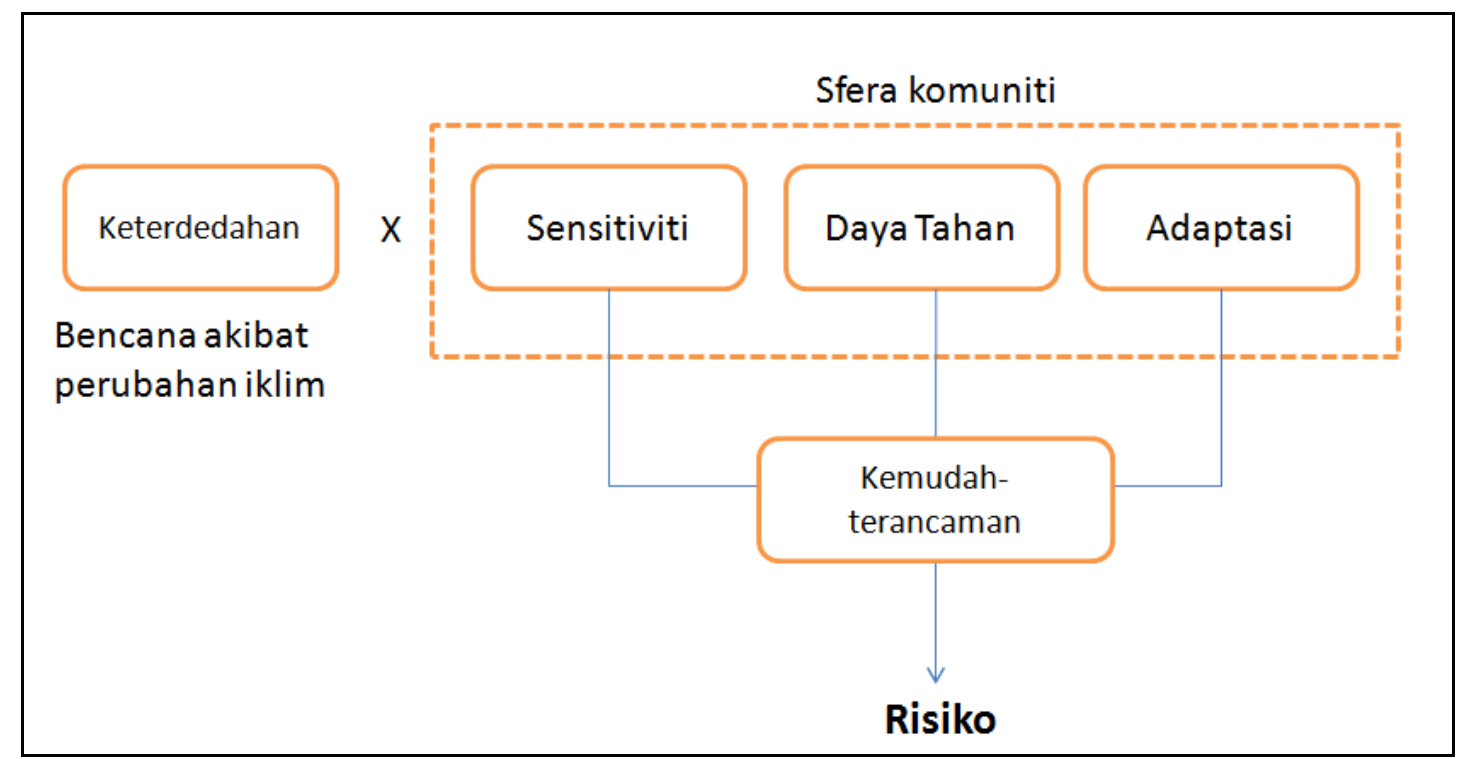

Sumber: Diubahsuai dari UNDP, 2004.

Rajah 2. Kerangka keterdedahan bencana dan sfera komuniti

Menurut Cutter (1994), tahap sensitiviti, daya tahan dan adaptasi masyarakat terhadap bencana adalah suatu yang abstrak dan sukar diukur. Justeru itu, instrumen kajian yang paling ideal adalah dengan mereka bentuk soalan yang bersesuaian untuk mengenal pasti tahap persepsi ataupun tanggapan mereka. Persepsi dan tanggapan individu dan komuniti terhadap isu perubahan iklim ini adalah faktor yang sangat signifikan dalam menentukan perancangan dasar serta program kesiapsiagaan terhadap bencana persekitaran.

\section{Metod dan kawasan kajian}

Pendekatan kajian ini adalah bersifat eksploratif, iaitu mengukur tanggapan manusia terhadap pengetahuan dan kesedaran komuniti pinggir pantai terhadap implikasi atau kesan kenaikan aras laut. Keseluruhan protokol metodologi kajian ini adalah berasaskan kepada kaedah survei umum menerusi penggunaan soal selidik yang telah direka bentuk serta teknik temu bual golongan nelayan pinggir pantai di kawasan kajian.

Secara ringkasnya, beberapa pertemuan bersama kumpulan penyelidik telah dilakukan bagi mengenal pasti item/soalan serta jangkaan konstruk yang bakal dibentuk berdasarkan kepada objektif kajian. Antara tema penting yang diteliti dalam kajian ini adalah tahap pengetahuan dan kesedaran oleh komuniti pinggir pantai terhadap sebarang aspek perubahan iklim dan kenaikan paras laut. Reka bentuk soal selidik telah dibuat supaya bersesuaian dengan keadaan tempatan dan jangkamasa kajian. Terdapat beberapa bentuk skala yang digunakan termasuklah skala Likert (5 mata), skala persetujuan (ya/tidak) serta penyataan yang bersifat soalan terbuka. 


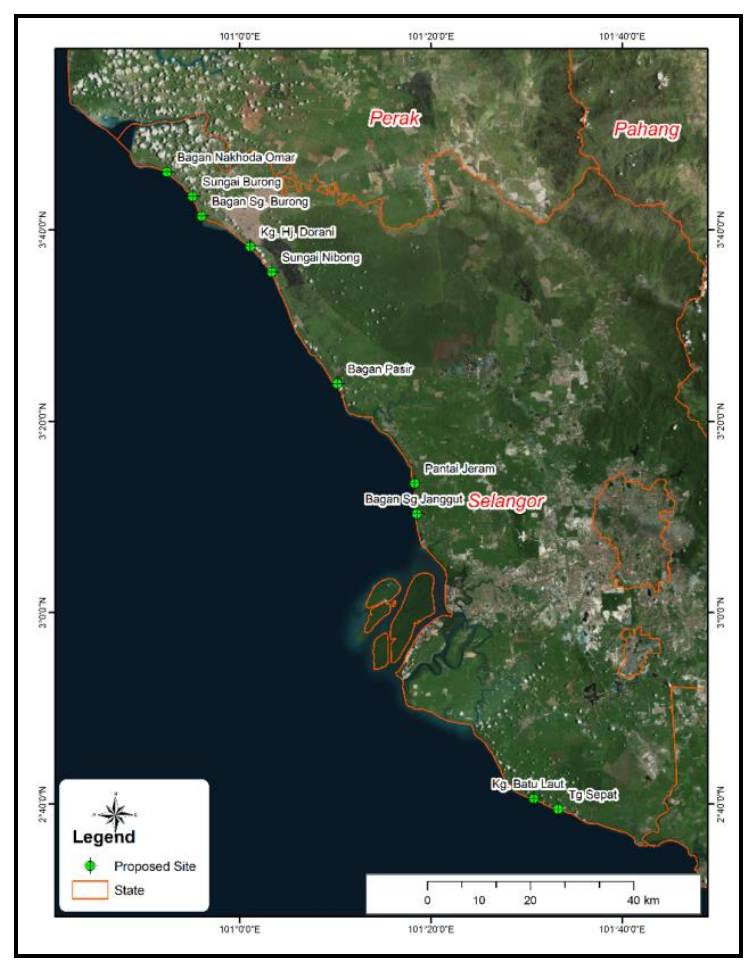

Rajah 3. Kawasan kajian

Keseluruhan item yang direka bentuk adalah bertujuan untuk membentuk suatu konstruk yang representasi keadaan sebenar di lapangan. Rajah 3 menunjukkan taburan kawasan kajian di sepanjang pinggir pantai Selangor. Sebanyak sepuluh petempatan utama komuniti pinggir pantai telah dipilih diantara daerah Kuala Selangor sehingga ke daerah Kuala Langat, Selangor (Jadual 2). Terdapat beberapa seksyen di dalam kerangka soal selidik yang direka khas untuk membentuk konstruk utama seperti di bawah:

(i) Pengetahuan responden

(ii) Kesedaran responden

(iii) Tanggapan atau persepsi responden, dan

(iv) Analisis keprihatinan terhadap kenaikan aras laut

Konstruk pengetahuan adalah merujuk kepada paras pengetahuan responden terhadap fenomena perubahan iklim serta hubung kaitannya dengan kenaikan aras laut di Malaysia Sebanyak 12 item atau soalan akan membentuk konstruk berkenaan. Konstruk kesedaran dibina berasaskan kepada 10 item yang berkaitan dengan tahap sensitiviti responden terhadap bahaya dan risiko kenaikan aras laut, manakala konstruk tanggapan (15 item) adalah konstruk yang dibina berasaskan keupayaan responden dalam menangani bahaya serta bentuk adaptasi yang berupaya dilaksanakan oleh mereka. Tahap keprihatinan terhadap perubahan iklim dibentuk berdasarkan kepada gabungan ketiga-tiga berkenaan:

Tahap keprihatinan perubahan iklim $=$ Skor tertinggi konstruk [Pengetahuan + Kesedaran + Tanggapan]/Jumlah responden per kawasan...........(i) 
Nilai tahap keprihatinan perubahan iklim ini adalah nilai gabungan skor konstruk bagi aspek pengetahuan, kesedaran dan juga tanggapan komuniti terhadap isu kenaikan aras laut di kawasan kajian. Maklumat berkenaan dianggap penting bagi mengenal pasti kedudukan atau ranking kawasan berkenaan berdasarkan keprihatinan mereka terhadap isu yang dibincangkan.

Setiap konstruk yang dibina melalui proses ujian kebolehpercayaan untuk menentukan kesesuaian kumpulan item yang digabung menjadi konstruk dan indeks berkenaan. Bagi memudahkan proses analisis, data asal telah menjalani laluan re-computing dan re-coding supaya terdapat keselarasan dalam pemberat dan skor yang dibentuk. Sebanyak 1050 responden telah dipilih secara rawak untuk survei soal selidik sekitar sepuluh petempatan utama zon pesisir pantai, mulai dari Bagan Nakhoda Omar, Sabak Bernam sehinggalah ke Tanjung Sepat, Kuala Langat Selangor (Jadual 2). Penelitian soal selidik telah dilakukan pada pertengahan Mac sehingga awal April 2017, melibatkan sebanyak lapan orang pembantu penyelidik. Satu kajian rintis yang menggunakan sebanyak 35 responden awal, khususnya di kawasan sekitar Kuala Langat, Selangor telah digunakan bagi mengenalpasti kebolehpercayaan (reliability) maklumat yang dikumpul. Nilai Cronbach alpha yang terhasil daripada kajian rintis berkenaan adalah $\alpha=$ 0.823 .

Jadual 2. Taburan responden

\begin{tabular}{lcc}
\hline Kawasan & Bilangan & Peratus \\
\hline Tg Sepat & 296 & 28.2 \\
Kg. Batu Laut & 224 & 21.3 \\
Bagan Sg Janggut & 39 & 3.7 \\
Pantai Jeram & 40 & 3.8 \\
Bagan Pasir & 80 & 7.6 \\
Sungai Nibong & 70 & 6.7 \\
Kg. Hj. Dorani & 122 & 11.6 \\
Bagan Sungai Burong & 45 & 4.3 \\
Sungai Burong & 94 & 9.0 \\
Bagan Nakhoda Omar & 40 & 3.8 \\
\hline
\end{tabular}

Julat skor bagi konstruk berkenaan dikategorikan dalam tiga paras, iaitu skor rendah, sederhana dan tinggi berdasarkan purata skor skala likert (Jadual 3). Pembentukan konstruk aspek pengetahuan, kesedaran dan persepsi adalah berdasarkan analisis CA merujuk kepada skor item keseluruhan yang terlibat untuk setiap konstruk. Keseluruhan analisis deskriptif dan kuantitatif data mentah dilakukan dalam persekitaran operasi SPSS ver20.

Jadual 3. Julat skor purata konstruk

\begin{tabular}{ll}
\hline Paras skor Konstruk & Julat skor \\
\hline Rendah & $1.00-2.33$ \\
Pertengahan & $2.34-3.67$ \\
Tinggi & $3.68-5.00$ \\
\hline
\end{tabular}

Dalam kajian ini, skop penelitian hanya tertumpu kepada tahap kemudahterancaman sosial, khususnya penduduk di sekitar zon pinggir pantai. Walaupun menurut Adger dan Kelly (1999) dan Clare dan Benhard (2010), aspek kemudahterancaman ekologi dianggap penting dalam melihat impak perubahan iklim, namun aspek berkenaan diabaikan bagi memberi penekanan yang menyeluruh terhadap komponen kemasyarakatan seperti yang dibincangkan dalam Rajah 2 . 


\section{Hasil kajian dan perbincangan}

Hasil analisis menunjukkan bangsa Melayu mendominasi petempatan di pinggir pantai Selangor (65.5\%), manakala bangsa Cina merupakan bangsa kedua terbesar di kawasan tersebut (25.5\%). Namun, pecahan orang Asli adalah lebih sedikit berbanding bangsa India di kawasan tersebut (Jadual 4).

Jadual 4. Profil responden

\begin{tabular}{lcc}
\hline Profil responden & Bilangan & Peratus \\
\hline Bangsa & 688 & 65.5 \\
Melayu & 268 & 25.5 \\
Cina & 34 & 3.2 \\
India & 60 & 5.7 \\
Orang Asli & & \\
Tahap pendidikan tertinggi & 144 & 13.7 \\
Tiada pendidikan formal & 311 & 29.6 \\
Sekolah rendah & 182 & 17.3 \\
SRP/PMR/PT3 & 269 & 25.6 \\
MCE/LCE/SPM & 101 & 9.6 \\
Sijil/Diploma/STPM/Asasi & 40 & 3.8 \\
Ijazah Sarjana Muda & 144 & 13.7 \\
Tiada pendidikan formal & 311 & 29.6 \\
Sekolah rendah & & \\
Pendapatan sendiri (bulanan) & 239 & 22.8 \\
Tiada Pendapatan & 56 & 5.3 \\
$<$ RM500 & 586 & 55.8 \\
RM501 - RM2000 & 121 & 11.5 \\
RM2001 - RM3000 & 42 & 4.0 \\
RM3001 - RM8000 & 6 & 0.6 \\
>RM8001 & &
\end{tabular}

Jadual 4 juga menunjukkan maklumat tahap pendidikan ketua isirumah serta pendapatan sendiri bulanan. Kedua-dua maklumat sosioekonomi berkenaan membuktikan lebih separuh daripada responden (60.6\%) mempunyai tahap pendidikan yang rendah setakat PMR ke bawah, manakala hampir $84.0 \%$ responden menyatakan pendapatan bulanan ketua isirumah adalah di bawah RM2000 sebulan.

Jadual 5 dan Jadual 6 masing-masing menunjukkan hasil kajian mengenai kedudukan rumah repsonden dengan garis pantai serta pengetahuan asas mereka terhadap hubungkaitan diantara peningkatan aras laut dengan perubahan iklim. Hampir 14.9\% kediaman responden adalah begitu hampir dengan pesisir pantai (kurang daripada $400 \mathrm{~m}$ ) dan kebanyakan lokasi kediaman adalah di kawasan bertopografi rendah (hasil pemerhatian lapangan). Namun, kedudukan zon kediaman yang kurang daripada $600 \mathrm{~m}$ dari gigi air (48.7\%) merupakan zon yang boleh dianggap mudah terdedah kepada peningkatan aras laut dalam jangkamasa panjang (IPI 2015). Kajian oleh IPI (2015) juga menjangkakan komuniti di dalam zon berkenaan adalah komuniti yang sangat 
mudah terancam dan terdedah kepada risiko bencana seperti banjir dan kehilangan kawasan daratan akibat hakisan yang serius.

Jadual 5. Jarak rumah daripada persisir pantai

\begin{tabular}{lcc}
\hline Jarak rumah daripada pesisir pantai & Bilangan & Peratus \\
\hline $0-200$ meter & 73 & 7.0 \\
$201-400$ meter & 83 & 7.9 \\
$401-600$ meter & 355 & 33.8 \\
$601-800$ meter & 277 & 26.4 \\
$801-1000$ meter & 262 & 25.0 \\
\hline
\end{tabular}

Jadual 6. Tahap pengetahuan terhadap peningkatan aras laut berlaku disebabkan oleh perubahan iklim

\begin{tabular}{lcc}
\hline & Bilangan & Peratus \\
\hline Ya & 450 & 42.9 \\
Tidak & 85 & 8.1 \\
Tidak pasti & 515 & 49.0 \\
\hline
\end{tabular}

Jadual 7 membuktikan bahawa pengetahuan responden terhadap hubung kaitan antara peningkatan aras laut dengan perubahan iklim agak kabur. Lebih separuh daripada responden (57\%) menyatakan ketidakpastian terhadap hubung kaitan berkenaan. Hasil kajian ini boleh dikaitkan dengan tahap latar belakang pendidikan responden yang kebanyakannya agak rendah (Jadual 5). Tahap pendidikan yang rendah di samping taraf sosioekonomi yang rendah menyebabkan pengetahuan mereka terhadap hubung kaitan antara peningkatan aras laut dengan perubahan iklim adalah lemah dan kabur.

Jadual 7. Tahap pengetahuan terhadap perubahan air laut/pantai oleh responden

\begin{tabular}{lcccccccc}
\hline \multirow{2}{*}{ Tempoh perbezaan } & \multicolumn{2}{c}{ Tidak } & \multicolumn{2}{c}{ Sama } & \multicolumn{2}{c}{ Meningkat } & \multicolumn{2}{c}{ Tidak pasti } \\
& Bil. & $(\boldsymbol{\%})$ & Bil. & $(\boldsymbol{\%})$ & Bil. & $(\boldsymbol{\%})$ & Bil. & $(\boldsymbol{\%})$ \\
\hline 5 tahun lepas (2011) & 33 & 3.1 & 245 & 23.3 & 662 & 63.0 & 110 & 10.5 \\
Kini (2016) & 7 & 0.7 & 296 & 28.2 & 696 & 66.3 & 51 & 4.9 \\
5 tahun akan datang (2021) & 5 & 0.5 & 106 & 10.1 & 699 & 66.6 & 240 & 22.9 \\
\hline
\end{tabular}

Oleh kerana populasi responden adalah majoritinya di kawasan yang berpotensi untuk merasai sebarang perubahan paras laut dan juga ekosistem pantai, Jadual 7 cuba mengenal pasti fakta berkenaan berdasarkan persepsi mereka. Didapati kebanyakan responden (hasil purata $=$ $65.3 \%$ ) bersetuju dengan fakta yang menyatakan wujud terhadap sebarang perubahan aras laut dan pinggir pantai sama ada lima tahun yang lepas, pada masa kini dan juga jangkaan pada masa hadapan.

Hasil tabulasi silang antara bangsa responden dengan ketiga-tiga konstruk berkenaan telah membuktikan jumlah bilangan responden yang berbangsa Melayu merupakan kumpulan terbesar yang mempunyai purata skor tertinggi bagi ketiga-tiga skor berkenaan (Jadual 8 - Jadual 10). Hampir $65.0 \%$ daripada responden yang mempunyai skor yang melebihi tahap sederhana ke atas adalah daripada responden berbangsa Melayu. Konstruk tanggapan dalam kalangan responden Melayu mencatatkan bilangan tertinggi yang direkodkan pada tahap tinggi $(\mathrm{N}=442)$. 
Jadual 8. Tabulasi silang di antara bangsa responden dan konstruk 'pengetahuan'

\begin{tabular}{lccc}
\hline Bangsa & \multicolumn{2}{c}{ Konstruk pengetahuan } & Jumlah \\
\cline { 2 - 3 } & Tahap sederhana & Tahap tinggi & \\
\hline Melayu & 309 & 379 & 688 \\
Cina & 159 & 109 & 268 \\
India & 21 & 13 & 34 \\
Lain-lain & 40 & 20 & 60 \\
\hline
\end{tabular}

Jadual 9. Tabulasi silang di antara bangsa responden dan konstruk 'kesedaran'

\begin{tabular}{lccc}
\hline Bangsa & \multicolumn{2}{c}{ Konstruk kesedaran } & Jumlah \\
\cline { 2 - 3 } & Tahap sederhana & Tahap tinggi & \\
\hline Melayu & 326 & 362 & 688 \\
Cina & 181 & 87 & 268 \\
India & 22 & 12 & 34 \\
Lain-lain & 48 & 12 & 60 \\
\hline
\end{tabular}

Jadual 10. Tabulasi silang diantara bangsa responden dan konstruk 'tanggapan'

\begin{tabular}{lccc}
\hline Bangsa & \multicolumn{2}{c}{ Konstruk tanggapan } & Jumlah \\
\cline { 2 - 3 } & Tahap sederhana & Tahap tinggi & \\
\hline Melayu & 246 & 442 & 688 \\
Cina & 157 & 111 & 268 \\
India & 12 & 22 & 34 \\
Lain-lain & 55 & 5 & 60 \\
\hline
\end{tabular}

Jadual 11 menunjukkan tahap keprihatinan kenaikan aras laut mengikut kawasan kajian. Hasil indeks ini telah menunjukkan kawasan Sungai Nibong, Kuala Selangor dianggap sebagai petempatan yang mempunyai tahap keprihatinan terhadap perubahan iklim ranking 1 dan mencatatkan nilai 0.971 nilai indeks keprihatinan yang tertinggi dalam kalangan responden. Kawasan Kg. Batu Laut, Kuala Langat didapati mempunyai sejumlah nilai tahap keprihatinan terhadap perubahan iklim 0.183 dan dianggap ranking terendah (ranking 10) dalam indeks berkenaan.

Hasil kajian yang menunjukkan perbezaan ketara di dalam indeks keprihatinan kenaikan aras laut adalah sangat penting khususnya dalam perancangan program adaptasi dan penyesuaian terhadap sebarang bencana berkaitan kenaikan paras laut. Kawasan petempatan Kg. Batu LautTanjung Sepat (daerah Kuala Langat) didapati mempunyai tahap keprihatinan perubahan iklim yang rendah berbanding kawasan yang lain. Terdapat beberapa alasan yang boleh dipertimbangkan di atas perkara berkenaan.

Antaranya adalah, faktor latar belakang responden yang terlibat dalam kajian ini. Boleh dikatakan majoriti (87.0\%) komuniti pinggir pantai yang dipilih di kawasan petempatan Kg Batu Laut-Tanjung Sepat (daerah Kuala Langat) merupakan golongan pendatang, iaitu golongan yang berhijrah ke kawasan berkenaan kerana mencari pekerjaan yang bersesuaian dengan mereka. Justeru, pengalaman dan tempoh masa menduduki kawasan petempatan berkenaan adalah tidaklah lama seperti di kawasan-kawasan petempatan yang lain seperti di Sungai Nibong, Kuala Selangor. 
Jadual 11. Tahap keprihatinan kenaikan aras laut mengikut kawasan

\begin{tabular}{lcc}
\hline Nama kawasan & $\begin{array}{c}\text { Tahap keprihatinan } \\
\text { perubahan iklim }\end{array}$ & Ranking \\
\hline Tg. Sepat & 0.201 & 9 \\
Kg. Batu Laut & 0.183 & 10 \\
Bagan Sungai Janggut & 0.769 & 7 \\
Pantai Jeram & 0.950 & 2 \\
Bagan Pasir & 0.825 & 4 \\
Sungai Nibong & 0.971 & 1 \\
Kg. Haji Dorani & 0.802 & 6 \\
Bagan Sungai Burong & 0.689 & 8 \\
Kg. Sungai Pulai & 0.935 & 3 \\
Bagan Nakhoda Omar & 0.824 & 5 \\
\hline
\end{tabular}

Jadual 12 menunjukkan keputusan ANOVA sehala antara tahap keprihatinan kenaikan aras laut dengan perbezaan bangsa responden di kawasan kajian. Hasil kajian menunjukkan terdapat perbezaan signifikan antara indeks keprihatinan kenaikan aras laut mengikut bangsa responden.

Jadual 12. Keputusan ANOVA sehala bagi bangsa dan tahap keprihatinan kenaikan aras laut

\begin{tabular}{lccccc}
\hline Bangsa & JKD & df & MKD & F & Sig. \\
\hline Antara kumpulan & 23.860 & 3 & 23.860 & 38.454 & .000 \\
Dalam kumpulan & 647.160 & 1046 & .620 & & \\
\hline
\end{tabular}

Hasil kajian ini telah menunjukkan perbezaan tahap keprihatinan komuniti terhadap variabiliti dan perubahan iklim di Selangor. Keputusan mengikut bangsa responden (Jadual 13) menyerlahkan lagi ketidakseragaman tahap keprihatinan yang wujud dalam kalangan mereka. Perbincangan kumpulan sasaran dan temu bual yang dilakukan telah menguatkan lagi kenyataan berkenaan. Hasil kajian yang berdasarkan kepada Jadual 10 hingga Jadual 12 telah membuktikan kenyataan berkenaan. Adalah didapati komuniti berbangsa Melayu mempunyai nilai skor konstruk 'pengetahuan', 'kesedaran' dan 'tanggapan' terhadap isu kenaikan aras laut di kawasan kajian, jika dibandingkan dengan bangsa lain.

Jadual 13. Keputusan ANOVA sehala bagi kawasan petempatan dan tahap keprihatinan kenaikan aras laut

\begin{tabular}{lccccc}
\hline Kawasan petempatan & JKD & df & MKD & F & Sig. \\
\hline Antara kumpulan & 66.33 & 9 & 7.370 & 103.5 & .000 \\
Dalam kumpulan & 74.01 & 1040 & .071 & & \\
\hline
\end{tabular}

Hasil kajian berkenaan boleh dikaitkan dengan model yang diketengahkan oleh Kollmus dan Agyeman (2002), persepsi dan kesedaran manusia terhadap alam sekitar disekelilingnya sangat bergantung kepada keyakinan (belief) seseorang (Rajah 4). Persepsi dan kesedaran seseorang akan membentuk sikap (attitude) dan seterusnya membawa kepada tindakan (action). 


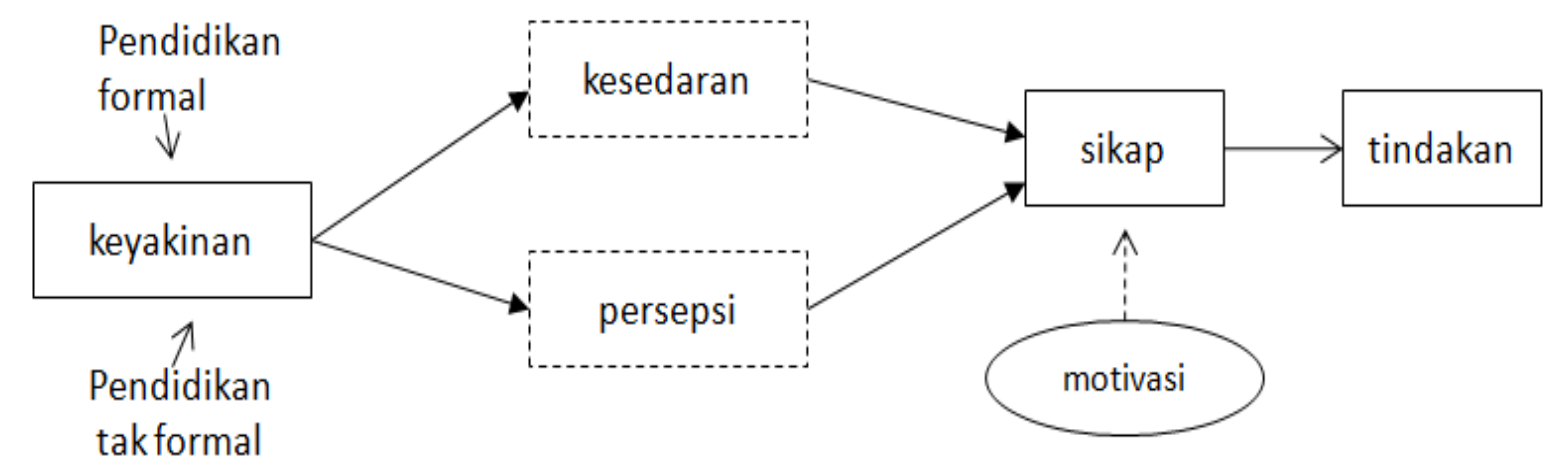

Sumber: Diubahsuai daripada Kollmus dan Agyeman, 2002.

Rajah 4. Model Perubahan Tingkah Laku

Memandangkan keyakinan seseorang yang beragama Islam terhadap isu persekitaran banyak dipengaruhi dan bermotivasikan oleh Al-Quran dan Al-Hadith (Rozita, 2002), sudah pasti persepsi dan kesedaran mereka terhadap isu persekitaran dipengaruhi oleh ajaran Islam. Perilaku altruistik ini yang diketengahkan oleh ajaran Al-Quran dan Al-Hadith dilihat sangat berpotensi dan berpengaruh membentuk persepsi masyarakat terhadap keprihatinan terhadap sebarang isu perubahan persekitaran di sekeliling mereka.

Terdapat isu dan fakta yang diutarakan oleh informan menerusi perbincangan telah membuktikan komuniti pesisir pantai, khususnya golongan Melayu mempunyai 'hubungan akrab' dengan laut. Majoriti informan pernah 'turun ke laut' sama ada sebagai nelayan sepenuh masa ataupun sebagai hobi dan kerja sampingan. Justeru itu, pengamatan mereka terhadap perubahan fizikal di ekosistem pantai adalah berdasarkan kepada pengalaman mereka sendiri. Oleh itu, tidak mustahil komuniti Melayu di pesisir pantai adalah golongan yang mempunyai tahap keprihatinan terhadap variabiliti dan perubahan iklim yang tertinggi. Walaupun dilihat hasil kajian ini membuktikan tahap keprihatinan terhadap perubahan iklim adalah tinggi dalam kalangan responden Melayu, namun latar belakang sosioekonomi yang rendah akan menghalang golongan tersebut untuk mengadaptasikan kehidupan mereka, khususnya apabila melibatkan kos pemuliharaan infrastruktur yang besar.

\section{Kesimpulan}

Kajian ini membuktikan tahap keprihatinan masyarakat pinggir laut adalah berbeza-beza mengikut lokasi petempatan. Perbezaan aspek latar diri, sosioekonomi serta profil responden telah membuktikan perbezaan berkenaan. Kajian sebegini adalah sangat penting terutamanya kepada pihak pelaksana pembangunan iaitu kerajaan menangani aspek keterdedahan dan keprihatinan masyarakat terhadap variabiliti dan perubahan aras laut di Selangor. Aspek kesedaran tentang bahaya perubahan iklim kepada peningkatan aras laut mengambarkan nilai hasilan statistik yang sederhana. Ini berkemungkinan terhasil akibat daripada tahap pendidikan dan taraf sosioekonomi mereka yang rendah. 
Walaupun hasil kajian membuktikan responden berbangsa Melayu mempunyai nilai skor tertinggi untuk konstruk pengetahuan, kesedaran dan tanggapan terhadap perubahan iklim, namun tidak semestinya golongan ini mempunyai kapasiti mengurus (coping capacity) serta peluang adaptasi yang tertinggi dalam kalangan masyarakat. Kajian ini juga membuktikan aspek pengetahuan dan kesedaran yang rendah ditambah dengan faktor kemudahterancam sosioekonomi komuniti pinggir pantai yang tinggi berpotensi membawa kepada bahaya (hazard) di masa akan datang.

\section{Penghargaan}

Penulisan ini adalah sebahagian daripada hasil kajian menerusi Projek 'Impact of shoreline changes to the coastal development' di bawah geran Penyelidikan Transdisplinari TRGS/1/2015/UKM/02/5/1.

\section{Rujukan}

Adger, W.N., \& Kelly P.M. (1999). Social vulnerability to climate change and the architecture of entitlements. Mitigation and Adaptation Strategies for Global Change, 4, 253-266.

Ahmad Jamaluddin, S. (2008). Climate change and variability. Second National Conference on Extreme Weather and Climate Change Understanding Science and Risk Reduction. Putrajaya International Convention Centre. 14-15 October.

Bindoff, N.L., Willebrand, J., Artale, V., Cazenave, A., Gregory, J., Gulev, S., Hanawa, K., Le Quéré, C., Levitus, S., Nojiri, Y., Shum, C.K., Talley, L.D., \& Unnikrishnan, A. (2007). Observations: Oceanic climate change and sea level. In Solomon, S., Qin, D., Manning, M., Chen, Z., Marquis, M., Averyt, K.B., Tignor, M., \& Miller, H.L. (Eds.), Climate Change 2007: The Physical Science Basis. Contribution of Working Group I to the Fourth Assessment Report of the Intergovernmental Panel on Climate Change. Report of the Intergovernmental Panel on Climate Change, Cambridge University Press, Cambridge.

Blaikie, P., Cannon, T., Davis, I., \& Wisner, B. (1994). At risk: Natural hazards, people's vulnerability, and disasters. London, Routledge.

Bird, E.C.F. (1985). Coastline changes: A global review. Chichester, John Wiley \& Sons.

Clare, L., \& Bernhard, W. (2010). Social and biophysical vulnerability of prehistoric societies to Rapid Climate Change. Documanta Praehistorica, 37, 269-284.

Cutter, S.L. (1994). Environmental risk and hazards. New Jersey, Prentice Hall.

Hansen, J. (2013). Climate sensitivity, sea level and atmospheric carbon dioxide. Royal Society Publishing, 371. http://dx.doi.org/10.1098/rsta.2012.0294

Hobfoll, S.E., Watson, P., Bell, P.C.C., \& Bryant, R.A. (2007). Five essential elements of immediate and mid-term mass trauma intervention: Empirical evidence. Psychiatry, 70, 283315. http://dx.doi.org/10.1521/psyc.2007.70.4.283

IPCC. (2013). Constraints on long-term climate change and the equilibrium climate sensitivity. Climate Change 2013: The Physical Science Basis - IPCC Working Group I Contribution to AR5. Intergovernmental Panel on Climate Change, Geneva, Switzerland.

IPI. (2015). Kesan hakisan pantai dan kenaikan paras laut di Batu Pahat. UKM, Bangi, Pusat Pencerapan Bumi. 
Jamaluddin, M.J. (2011). Perubahan persekitaran fizikal dan keselamatan manusia. Malaysian Journal of Environmental Management, 12(2), 3-10.

Kollmuss, A., \& Agyeman, J. (2010). Mind the gap: Why do people act environmentally and what are the barriers to pro-environmental behavior? Environmental Education Research, 8(3), 239-260. http://dx.doi.org/10.1080/13504620220145401

NAHRIM. (2010). The study of the impact of climate change on sea level rise in Malaysia (Final Report), National Hydraulic Research Institute Malaysia.

Nor Aslinda Awang \& Mohd Radzi. (2013). Sea level rise in Malaysia: Hydro link number 2/2013.

NASA. (2018). Sea level: Latest measurement November 2017. Retrieved from https://climate.nasa.gov/vital-signs/sea-level.

Nicholls, R.J., Woodroffe, C., \& Burkett, V. (2009). Coastline degradation as an indicator of global change. In Letcher, T.M. (Ed.), Climate change: Observed impacts on planet earth (pp. 409-424). Amsterdam, Elsevier.

Noorazuan, M.H. (2015). Kecelaruan iklim global: Satu analisis awal. Geografia: Malaysian Journal of Society and Space, 11(11), 24-35.

Priskin, J. (2003). Tourist perceptions of degradation caused by coastal nature-based recreation. Environmental Management, 32, 189-204. http://dx.doi.org/10.1007/s00267-002-2916-z

Rozita. (2002). Literasi alam sekitar menurut paradigma agama. Jurnal Pengajian Umum, 3, 137-147.

Shear, M.K., McLaughlin, K.A., Ghesquiere, A., Gruber, M.J., Sampson, N.A., \& Kessler, R.C. (2011). Complicated grief associated with hurricane Katrina. Depression and Anxiety, 28, 648-657. http://dx.doi.org/10.1002/da.20865.

Slovic, P. (2001). The perception of risk. Earthscan, London.

The Lancet. (2017). Countdown: Tracking progress on health and climate change. In Nick Watts, W Neil Adger, Sonja Ayeb-Karlsson, Yuqi Bai, Peter Byass, Diarmid Campbell-Lendrum, Tim Colbourn, Peter Cox, Michael Davies, Michael Depledge, \& others. The Lancet, 389, 10074.

Tjia, H.D. (1987). Geomorfologi. Kuala Lumpur, Dewan Bahasa dan Pustaka. 